\title{
DRYWELLS DIMENSIONING: ANALOGY BETWEEN WATER FLOW IN SOIL AND HEAT FLUX IN MEDIA SOLIDS
}

\author{
Armando T. Ferreira ${ }^{1}$, Marina S. de O. Ilha ${ }^{2 *_{*}}$ \\ ${ }^{1}$ Federal Institute of Education, Science and Technology of Sao Paulo. Brazil \\ ${ }^{2}$ Department of Architecture and Building Construction, School of Civil Engineering, Architecture and Urban \\ Design University of Campinas, Brazil
}

Received 17 June 2019; received in revised form 18 June 2020; accepted 20 November 2020

\begin{abstract}
The drywell is an on-lot drainage system, which is composed by an excavation in the soil lined with a perforated piped and gravel at the bottom and sides. There are many models for on lot systems dimensioning, which were initially developed for agriculture areas or for simulation of water percolation in porous media, thus, they are not fully optimized for small areas like urban lots. This article proposes a model for dimensioning drywells, which is based on physical and hydrological characteristics of the installation site. It was developed using the analogy between water flow in soil and the heat flux in media solids. Results obtained with the proposed model were statistically similar $(\mathrm{p}>0.05)$ to those obtained with experimental data.
\end{abstract}

Keywords: On-lot drainage; drywell; analogy; infiltration.

(C) 2020 Journal of Urban and Environmental Engineering (JUEE). All rights reserved.

\footnotetext{
* Correspondence to: Marina S. de O. Ilha, Tel.: +551935212306

E-mail: milha@fec.unicamp.br
} 


\section{INTRODUCTION}

The uncontrolled growth of impermeable areas in cities results in increase in surface runoff, which alters the runoff hydrograph with the increase in peak flow and the consequent floods. In this context, instead of conducting all the runoff generated by urban drainage systems outside the cities, there is a need to associate measures that deal with the management of rainwater in the place where runoff is generated.

On-lot drainage systems are auxiliary systems based on rainwater retention and detention techniques, including infiltration. As shown by Reis (2018), infiltration systems are hybrid systems that sometimes act as retention, when water is stored inside the system and then be infiltrated over time and, at others, as detention, when the system reaches its maximum volume capacity and starts to overflow, while a portion of water is infiltrated.

In general, in infiltration systems, rainwater is directed to a structure (or component) that is sized to store a certain volume of water while slowly infiltrating the soil.

The dry-well, which consists of an excavation in the ground, usually lined with a concrete tube drilled with gravel at the bottom and on the sides, protected by a layer of geotextile, is an example of an infiltration system.

The equation of the flow of water and air through the soil to represent the water content along the depth was proposed by Green and Ampt (1911), constituting the equations of the infiltration capacity in the soil.

Richards (1931) developed an equation with the total water potential that is equal to the sum of the capillary potential and the gravitational potential, which is used in the current equations to represent the flow of water in the soil. The Richards' equation is derived from the Darcy equation and determines the dynamics of water in an unsaturated soil in the vertical direction.

The Richards' equation is difficult to solve, considering the relationships among the variables involved in the process of water infiltration in the soil and the numerical solutions are very complex and require detailed soil data. As a result, several models were developed for an approximate analytical solution (Becker, 2016). Different approaches have been used in these models, which can be summarized in numerical and computational resolutions of the equations that expand the classic Richards's equation (Del Rio and López de Haro, 1991; El-Kadi and Ge, 1993).

A systematic mapping study (SMS) of articles in English published in journals indexed in three international databases (Web of Science; Scopus e Engineering Village-Compendex) with the expression ["water infiltration" AND model*] in 2017 resulted in 94 documents adhering to the research theme, including backward searching, according to Levy and Ellis (2006): $40.4 \%$ of these articles use mathematical modeling; $25.5 \%$ use modeling by physical theories and $34.0 \%$ use partial differential equations solving (Figure 1).

Twenty-five percent of the 38 articles that show mathematical modeling employ the techniques of: Finite elements (Arampatzis et al., 2001; Baca et al., 1997; Bause and Knabner, 2004; Bergamaschi and Putti, 1999; Duchene et al., 1994; Farthinet al., 2003; Hou and $\mathrm{Wu}, \mathrm{1997}$; Ju and Kung, 1997; Lee et al., 2004; Norambuena-Contreras et al., 2012; Solin and Kuraz, 2011; Tan et al., 2004; Wu, 2010); Neural networks (Chua and Wong, 2010; Dorofki et al., 2014; Jain and Kumar, 2006; Goldshleger et al., 2012; Nestorl, 2006; Parchami-Aragui et al., 2013) and Finite volume discretization (Aravena and Dussailant, 2009; Calvo and Lisbona, 2001; Huber and Helmig, 2000; Lunati and Jenny, 2006; Manzini and Ferraris, 2004); Twarakavi et al., 2008).

The technique of finger phase field by gravity is used by $22 \%$ of the 23 articles that shows modeling by physical theories (Cueto-Felgueroso and Juanes, 2009a; 2009b; Eliassi and Glass, 2003; Furst et al., 2009; Glass and Yarrington, 2003) and $40 \%$ of the 32 articles that show models based on partial differential equations solving employ the techniques of: Laplace transforms (Fytius and Smith, 2001; Ginting, 2012; Jenkins et al.,2001; Nikzad et al. , 2016; Srivastava and Yeh, 1991; $\mathrm{Wu}$ et al., 2012; Zaradny, 2008; and Pedotransfer functions (Baker and Ellison, 2008; Dashtaki et al., 2010; Dhikary et al., 2008; Haghverdi et al., 2012; Schaap and Leji, 1998; Tomasella et al. , 2003).

However, as shown by Li and Babcock Jr (2014), most models for assessing the performance of infiltration systems are not fully optimized for the specific characteristics of on-lot drainage systems, since their initial development was made for agriculture or the simulation of water percolation in porous media.

In addition, according to Graham et al (2014), the current modeling software were developed for the determination of peak flows and dimensioning of transport systems and are, for the most part, unsuitable for spatially distributed control systems, as is the case of on-lot drainage systems.

According to Reis (2018), models currently used hardly represent with the expected performance the hydrological processes resulting from low impact development strategies. This author also emphasizes that this statement is shared by different researches, such as: Krebs et al. (2016); Zhang and Guo (2014); Li and Babcock Jr. (2014); Burszta-Adamiak and Mrowiec (2013); Lee et al. (2013); Christianson et al. (2012); Furumai et al. (2005); and Graham et al. (2004). 


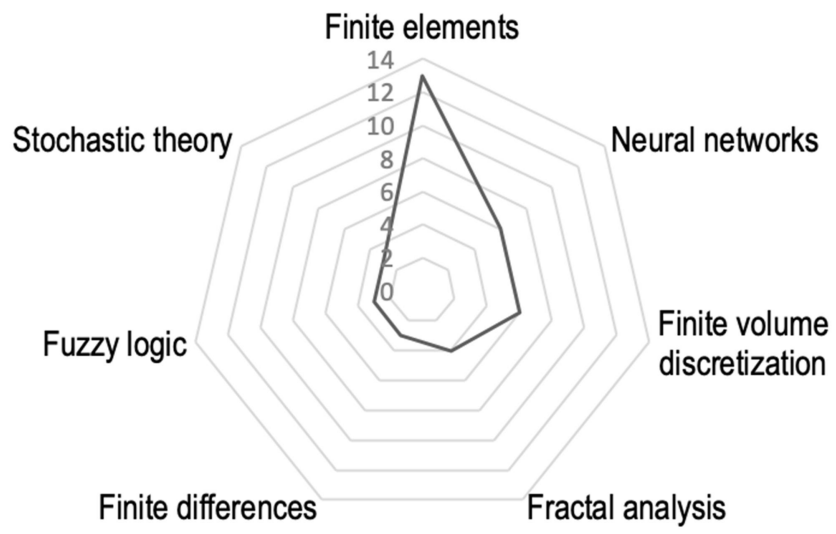

\section{Modeling by physical theories}

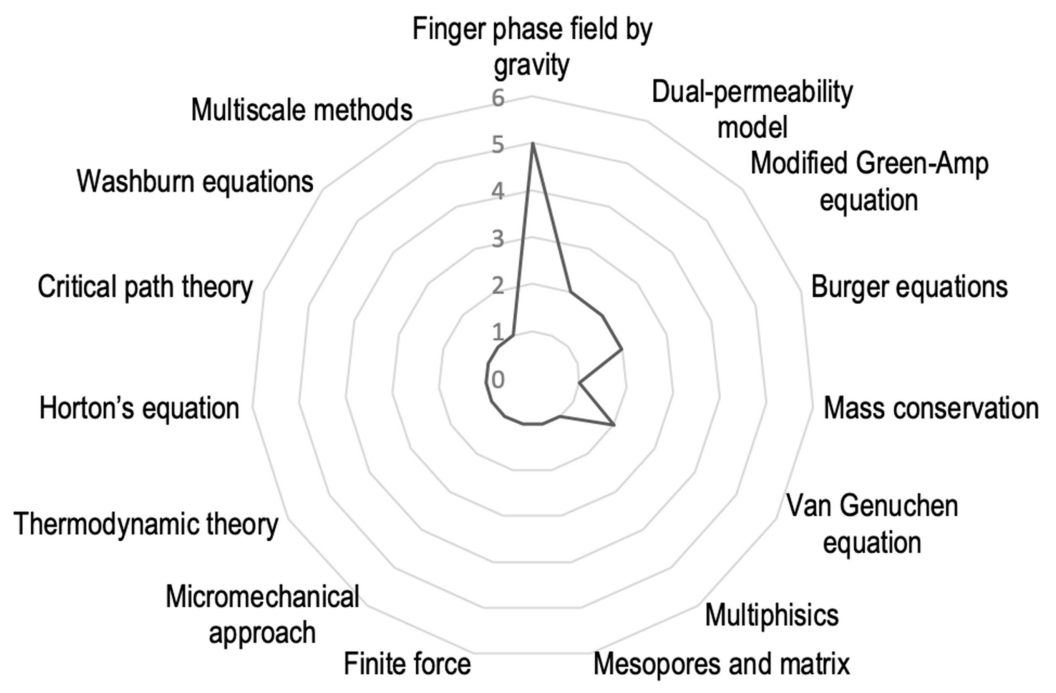

\section{Modeling based on partial differential equations solving}

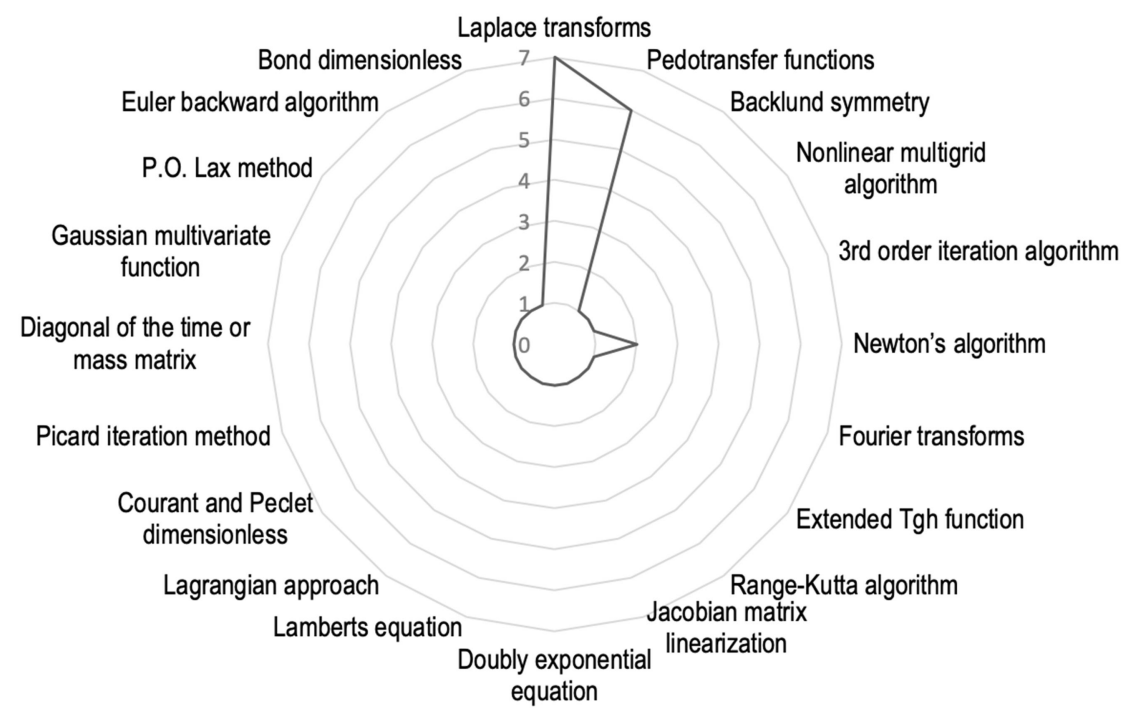

Fig. 1: Results of the SMS - 98 articles published in English. 
In this context, the present work presents an alternative model for the dimensioning of drywells, which starts from a unidirectional water flow and incorporates interface coefficients to represent the threedimensional behavior of the water flow in the soil. The proposed formulation is based in the theory of the Domain Transfer via Analogy - TDA (Klenk and Forbus; 2009). TDA uses the knowledge of a base (or source) domain, which already has its equation consolidated, to explain a problem or issue to be resolved - the target domain. A domain can be composed of a system of objects or entities; attributes (description of objects) or relationships between objects (GENTNER, 1983).

\section{MATERIALS AND METHOD}

TDA is usually composed of 4 stages (Klenk and Forbus, 2009): definition of the base domain; definition of the target domain, development of correspondences between the two domains and application. In the present study, the target domain is composed of the relationships between the determinants of the water flow in the soil, more specifically, those involved in determining the filling time of drywells.

The filling time of an on-lot drainage system is defined as the period between the moment the first raindrop reaches the system until the moment when it overflows, when the water is directed to the urban drainage system. For the proper determination of the filling time of a dry-well, it is important to know the interaction between the soil layers, since it has a heterogeneous composition.

The interaction between different materials is already well resolved when considering the phenomenon of heat transfer in solid media (Aseka, 2003; Mendes, 1997; Upadhyay et al., 1975). Thus, the relationships between the variables that determine the heat flux in solid media were selected as the base domain.

The Laplace equation, which is used to determine the heat flux in solid media, combines the Fourier equation and the general thermal conduction equation. For the flux in a single direction (x) in a transient regime, with the temperature varying in time and without generating internal heat, the general equation of thermal conduction is expressed in Eq. 1 (Kreith and Bohn, 2003):

$$
\mathrm{T}_{\mathrm{i}+1}^{\mathrm{m}}=\mathrm{T}_{\mathrm{i}}^{\mathrm{m}}+\alpha \Delta \mathrm{t}\left[\frac{\left(\mathrm{T}_{\mathrm{i}+1}^{\mathrm{m}}+\mathrm{T}_{\mathrm{i}-1}^{\mathrm{m}}+2 \mathrm{~T}_{\mathrm{i}}^{\mathrm{m}}\right)}{\Delta \mathrm{x}}\right]
$$

with (Eq.2):

or $(\mathbf{E q . 3})$ :

$$
\alpha=\frac{\mathrm{k}}{\rho \mathrm{c}}
$$

$$
\mathrm{T}_{\mathrm{i}+1}^{\mathrm{m}}=\mathrm{T}_{\mathrm{i}}^{\mathrm{m}}+\frac{\mathrm{k} \Delta \mathrm{t}}{\rho \mathrm{c}}\left[\frac{\left(\mathrm{T}_{\mathrm{i}+1}^{\mathrm{m}}+\mathrm{T}_{\mathrm{i}-1}^{\mathrm{m}}+2 \mathrm{~T}_{\mathrm{i}}^{\mathrm{m}}\right)}{\Delta \mathrm{x}^{2}}\right]
$$

where: Temperature of the layer $\mathrm{i}+1$ at time $\mathrm{m}\left[{ }^{\circ} \mathrm{C}\right]$

$\mathrm{T}_{\mathrm{i}+1}^{\mathrm{m}}$

$\mathrm{T}_{\mathrm{i}}^{\mathrm{m}}$

$\mathrm{T}_{\mathrm{i}-1}^{\mathrm{m}}$

$\mathrm{k}$

$\rho$

$c$

$\Delta \mathrm{t}$

Similarly, the Richards equation is used in the target domain to determine the water flow in the vertical direction in the unsaturated soil. Richards equation combines Darcy and continuity equations. For saturated soils, with flow in a single direction ( $\mathrm{x}$ ) and transient regime, where moisture varies over time, and without generating internal flow, Eq. 4 can be used:

$$
\mathrm{h}_{\mathrm{i}+1}^{\mathrm{m}}=\mathrm{h}_{\mathrm{i}}^{\mathrm{m}}+\alpha \Delta \mathrm{t}\left[\frac{\left(\mathrm{h}_{\mathrm{i}+1}^{\mathrm{m}}+\mathrm{h}_{\mathrm{i}-1}^{\mathrm{m}}+2 \mathrm{~h}_{\mathrm{i}}^{\mathrm{m}}\right)}{\Delta \mathrm{x}^{2}}+\frac{\mathrm{q}}{\mathrm{k}}\right]
$$

or $(\mathbf{E q . 5})$ :

$$
\mathrm{h}_{\mathrm{i}+1}^{\mathrm{m}}=\mathrm{h}_{\mathrm{i}}^{\mathrm{m}}+\frac{\mathrm{k} \Delta \mathrm{t}}{\rho \mathrm{c}}\left[\frac{\left(\mathrm{h}_{\mathrm{i}+1}^{\mathrm{m}}+\mathrm{h}_{\mathrm{i}-1}^{\mathrm{m}}+2 \mathrm{~h}_{\mathrm{i}}^{\mathrm{m}}\right)}{\Delta \mathrm{x}^{2}}\right]
$$

with (Eq.6):

$$
\alpha=\frac{\mathrm{k}}{\rho \mathrm{c}}
$$

where:

$\mathrm{h}_{\mathrm{i}+1}^{\mathrm{m}} \quad$ Moisture of layer $\mathrm{i}+1$ at time $\mathrm{m}[\%]$

$\mathrm{h}_{\mathrm{i}}^{\mathrm{m}} \quad$ Moisture of layer i at time $\mathrm{m}[\%]$

$\mathrm{h}_{\mathrm{i}-1}^{\mathrm{m}} \quad$ Moisture of layer $\mathrm{i}-1$ at time $\mathrm{m}[\%]$

$\Delta \mathrm{t}$ Time increment $[\mathrm{s}]$

q Affluent flow in the system $\left[\mathrm{m}^{3} / \mathrm{s}\right]$

$\mathrm{k} \quad$ Hydraulic conductivity $[\mathrm{m} / \mathrm{s}]$

$\rho \quad$ Specific mass $\left[\mathrm{kg} / \mathrm{m}^{3}\right]$

c Porosity [\%]

Eq. 6 can also be expressed in terms of the only time-varying parameter, which is moisture, resulting in Eq. 7:

$$
h_{i+1}^{m}=h_{i}^{m}+\alpha \Delta t\left[\frac{\left(h_{i+1}^{m}+h_{i-1}^{m}+2 h_{i}^{m}\right)}{\Delta x^{2}}+\frac{q}{k}\right]
$$

The heat flux causes the variation in the internal energy of a solid. Similarly, the flow of water from the infiltration system causes variation in the moisture of the underlying layers. Fig. 2 illustrates this analogy: on the left side, the heat flux from material i-1 to material $i+1$ causes an increase of the temperature of material $i$ in the time interval $\Delta \mathrm{t}$ (the temperature $\mathrm{T}_{\mathrm{i}}^{\mathrm{m}+1}$ is higher than the temperature $\mathrm{T}_{\mathrm{i}}^{\mathrm{m}}$ ); similarly, on the right side, the flow of water from layer $i-1$ to layer $i+1$ causes an increase in the moisture of the layer I in the interval $\Delta t$ (the moisture $\mathrm{h}_{\mathrm{i}}^{\mathrm{m}+1}$ is higher than the moisture $\mathrm{h}_{\mathrm{i}}^{\mathrm{m}}$ ). 
Thus, similarly, the moisture of layer $\mathrm{i}$ at time $\mathrm{m}+1$ can be determined by Eq. 8:
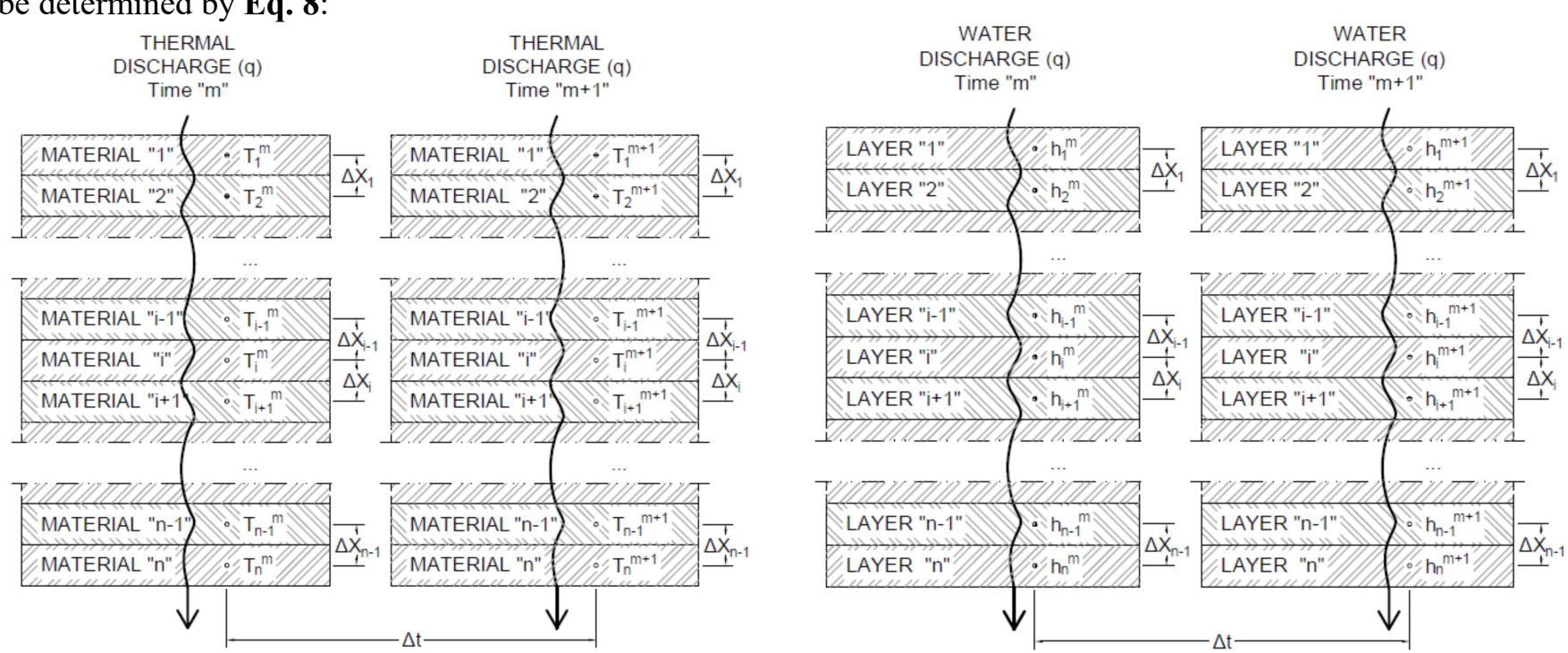

Fig. 2: Analogy between the temperature variation caused by the heat flux (thermal discharge) through the layers of a solid and the moisture variation caused by the water flow through the soil layers.

$$
\mathrm{h}_{\mathrm{i}}^{\mathrm{m}+1}=\mathrm{h}_{\mathrm{i}}^{\mathrm{m}}+\frac{\mathrm{k}_{\mathrm{i}} \Delta \mathrm{t}}{\Delta \mathrm{X}^{2} \eta_{\mathrm{s}, \mathrm{i}}}\left(\mathrm{h}_{\mathrm{i}+1}^{\mathrm{m}}-2 \mathrm{~h}_{\mathrm{i}}^{\mathrm{m}}+\mathrm{h}_{\mathrm{i}-1}^{\mathrm{m}}\right)
$$

where

$\mathrm{h}_{\mathrm{i}}^{\mathrm{m}+1}$ Moisture of soil layer $\mathrm{i}$ at time $\mathrm{m}+1$ [\%]

$\mathrm{h}_{\mathrm{i}}^{\mathrm{m}} \quad$ Moisture of soil layer $\mathrm{i}$ at time $\mathrm{m}[\%]$

$\mathrm{k}_{\mathrm{i}}$ Hydraulic conductivity of the soil layer $\mathrm{m}$

$[\mathrm{m} / \mathrm{s}]$

$\Delta \mathrm{t} \quad$ Time increment $[\mathrm{s}]$

$\Delta \mathrm{X} \quad$ Soil layer thickness [m]

$\eta_{\mathrm{s}, \mathrm{i}} \quad$ Porosity of the soil layer i [\%]

$\mathrm{h}_{\mathrm{i}+1}^{\mathrm{m}} \quad$ Moisture of soil layer $\mathrm{i}+1$ at time $\mathrm{m}$ [\%]

$\mathrm{h}_{\mathrm{i}-1}^{\mathrm{m}}$ Moisture of soil layer i-1 at time $\mathrm{m}[\%]$

Data collected in an experimental installation composed of two drywells (Fig. 3), each with an internal diameter of $1.10 \mathrm{~m}$, total depth of $1.50 \mathrm{~m}$ and effective depth of 0,87 were used for the validation of the proposed model. The drywells were made with perforated concrete pipes and a gravel layer at the bottom with a thickness of $0,50 \mathrm{~m}$. The drywells were dimensioned for a design flow rate of $6.54 \mathrm{~m}^{3} \cdot \mathrm{h}^{-1}$, which is equivalent to a rain with a return period of 2 years and duration of $10 \mathrm{~min}$, determined by the equation proposed by Zuffo and Leme (2005).

The conductivity of the soil in the experimental area was determined by Reis (2018) and it is equal to 1.382 * $10^{-5} \mathrm{~m} \cdot \mathrm{s}^{-1}$ and porosity is $40.84 \%$. The water level in each layer was determined at 10 -second intervals using level sensors installed inside the experimental drywells.

Thirty-one design flow rates were simulated, resulting in 4.303 water level values as a function of time.

According to Reis and Ilha (2014), before each test, the dry-well were filled and emptied three time in a row, in order to increase the moisture of the soil in the contour region, creating a more unfavorable operation condition. Thus, only the data collect after the fourth filling procedure were considered in the analyses.

\section{RESULTS AND DISCUSSION}

Four layers were considered for the model formulation (Fig. 4):

a) Gravel layer at the bottom of the dry-well;

b) First layer of soil below the gravel layer;

c) i-th layer of soil; and

d) n-th layer of soil.
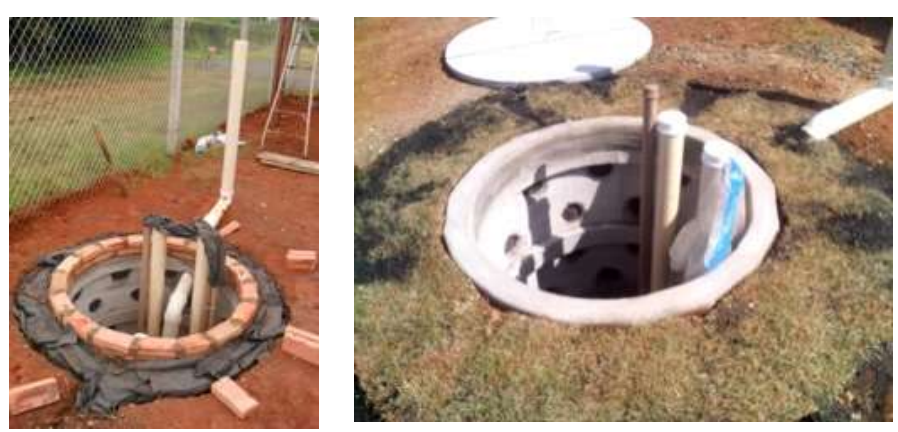

Fig. 4 Experimental dry-well. Source: Ferreira, Reis and Ilha (2016) 


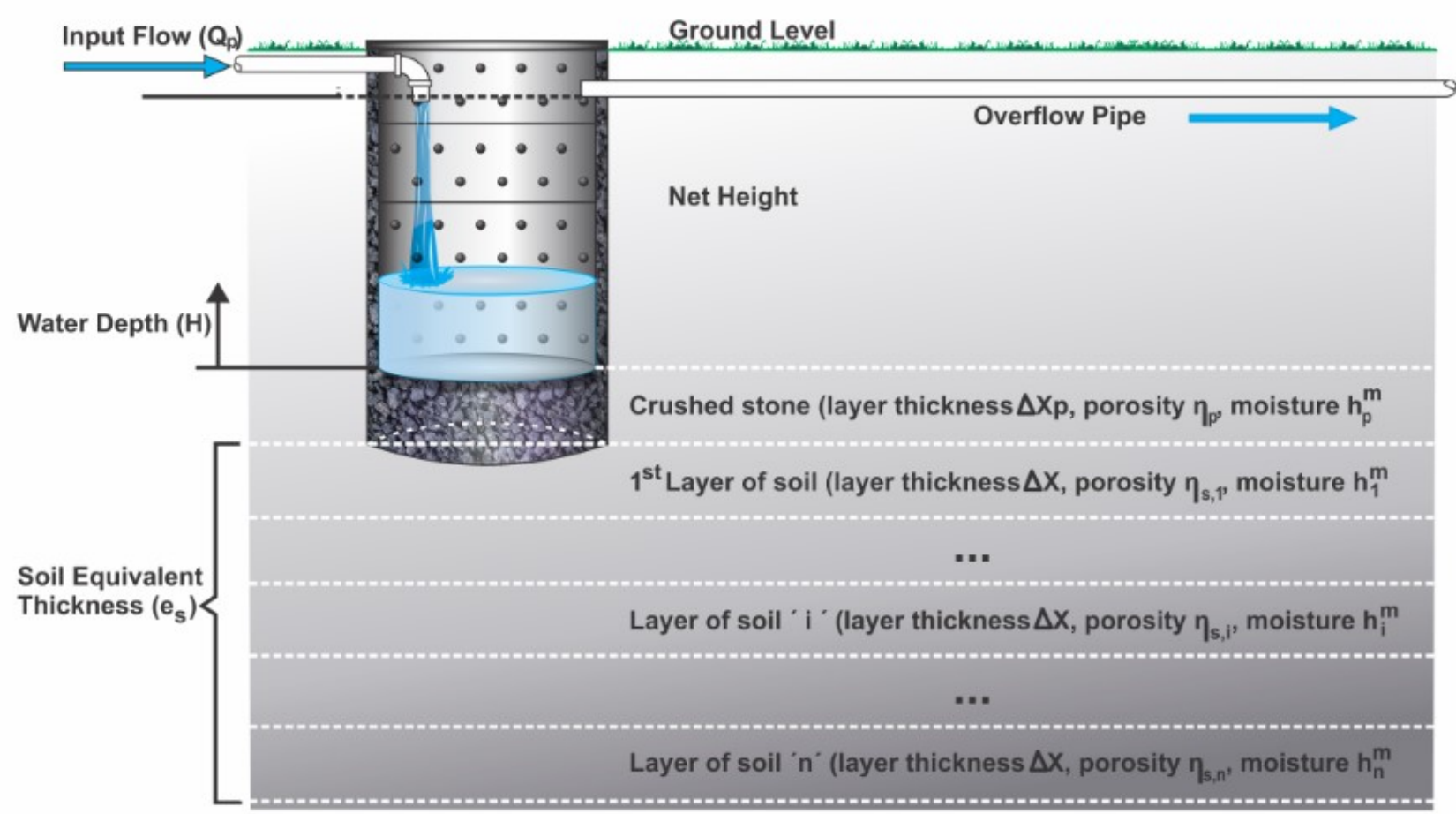

Fig. 4 Scheme of the on-lot drainage system (dry-well + soil) used for the formulation of the model.

The gravel layer receives the contribution of the rain and its moisture varies over time according to Eq. 9:

$$
\mathrm{h}_{\mathrm{p}}^{\mathrm{m}+1}=\mathrm{h}_{\mathrm{p}}^{\mathrm{m}}+\frac{\left[2 \mathrm{k}_{\mathrm{s}, 1} \mathrm{~A}_{\mathrm{p}}\left(\mathrm{h}_{1}^{\mathrm{m}}-\mathrm{h}_{\mathrm{p}}^{\mathrm{m}}\right)\right]+\mathrm{Q}_{\mathrm{p}}}{\Delta \mathrm{X}}\left(\frac{\Delta \mathrm{t}}{\mathrm{A}_{\mathrm{p}} \eta_{\mathrm{p}} \Delta \mathrm{X}_{\mathrm{p}}}\right)
$$

Where:

$\mathrm{h}_{\mathrm{p}}^{\mathrm{m}+1} \quad$ Moisture of the gravel layer $\mathrm{p}$ at time $\mathrm{m}+1$ [\%]

$\mathrm{h}_{\mathrm{p}}^{\mathrm{m}} \quad$ Moisture of the gravel layer $\mathrm{p}$ at time $\mathrm{m}[\%]$

$\mathrm{h}_{1}^{\mathrm{m}} \quad$ Moisture of the first layer of soil below the gravel layer at time $\mathrm{m}[\%]$

$\mathrm{k}_{\mathrm{s}, 1} \quad$ Hydraulic conductivity of the first layer of soil [m/s]

$A_{p} \quad$ Gravel area in the dry-well $\left[\mathrm{m}^{2}\right]$

$\Delta \mathrm{X}_{\mathrm{p}} \quad$ Gravel layer thickness [m]

$\Delta \mathrm{X} \quad$ Layer thickness [m]

$\mathrm{Q}_{\mathrm{p}} \quad$ Design flow rate $\left[\mathrm{m}^{3} \cdot \mathrm{h}^{-1}\right]$

$\Delta \mathrm{t} \quad$ Time interval used for each iteration [s]

The soil layer below the gravel layer receives the contribution of the upper layer and the moisture varies over time according to Eq. 10:

Where:

$$
\mathrm{h}_{1}^{\mathrm{m}+1}=\mathrm{h}_{1}^{\mathrm{m}}+\frac{2 \mathrm{~h}_{\mathrm{b}}^{\mathrm{m}}-3 \mathrm{~h}_{1}^{\mathrm{m}}+\mathrm{h}_{2}^{\mathrm{m}}}{\Delta \mathrm{X}}\left(\frac{\mathrm{k}_{\mathrm{s}, 1} \Delta \mathrm{t}}{\Delta \mathrm{X} \eta_{\mathrm{s}, 1}}\right)
$$

$\mathrm{h}_{1}^{\mathrm{m}+1}$ Moisture of the first layer of soil below the gravel layer at time $\mathrm{m}+1[\%]$

$\mathrm{h}_{1}^{\mathrm{m}} \quad$ Moisture of the first layer of soil below the gravel layer at time $\mathrm{m}[\%]$

$\mathrm{h}_{2}^{\mathrm{m}} \quad$ Moisture of the second layer of soil below the gravel layer at time $\mathrm{m}[\%]$

$\mathrm{k}_{\mathrm{s}, 1} \quad$ Hydraulic conductivity of the first layer of soil $[\mathrm{m} / \mathrm{s}]$
$\Delta \mathrm{X}$

$\Delta \mathrm{t} \quad$ Time interval used for each iteration [s]

$\eta_{\mathrm{s}, 1} \quad$ Porosity of the first layer of soil [\%]

Similarly, Eq. 11 can be used to determinate the temporal variation in moisture of a generic layer $i$ and Eq. 12 for the n-th layers of soil below the gravel layer at the bottom of the dry-well:

$$
\begin{gathered}
\mathrm{h}_{\mathrm{i}}^{\mathrm{m}+1}=\mathrm{h}_{\mathrm{i}}^{\mathrm{m}}+\frac{\left(\mathrm{h}_{\mathrm{i}+1}^{\mathrm{m}}-2 \mathrm{~h}_{1}^{\mathrm{m}}+\mathrm{h}_{\mathrm{i}-1}^{\mathrm{m}}\right)}{\Delta \mathrm{X}}\left(\frac{\mathrm{k}_{\mathrm{s}, \mathrm{i}} \Delta \mathrm{t}}{\Delta \mathrm{X} \eta_{\mathrm{s}, \mathrm{i}}}\right) \\
\mathrm{h}_{\mathrm{n}}^{\mathrm{m}+1}=\mathrm{h}_{\mathrm{n}}^{\mathrm{m}}+\frac{\left(\mathrm{h}_{\mathrm{n}}^{\mathrm{m}}-\mathrm{h}_{\mathrm{n}-1}^{\mathrm{m}}\right)}{\Delta \mathrm{X}}\left(\frac{\mathrm{k}_{\mathrm{s}, \mathrm{n}} \Delta \mathrm{t}}{\Delta \mathrm{X} \eta_{\mathrm{s}, \mathrm{n}}}\right)
\end{gathered}
$$

Where:

$\mathrm{h}_{\mathrm{i}}^{\mathrm{m}+1}$ Moisture of the soil layer i at time $\mathrm{m}+1$ [\%]

$\mathrm{h}_{\mathrm{i}}^{\mathrm{m}} \quad$ Moisture of the soil layer $\mathrm{i}$ at time $\mathrm{m}[\%]$

$\mathrm{h}_{\mathrm{n}}^{\mathrm{m}+1}$ Moisture of the soil layer $\mathrm{n}$ at time $\mathrm{m}+1[\%]$

$\mathrm{h}_{\mathrm{n}}^{\mathrm{m}} \quad$ Moisture of the soil layer $\mathrm{n}$ at time $\mathrm{m}$ [\%]

$\mathrm{k}_{\mathrm{s}, \mathrm{i}} \quad$ Hydraulic conductivity of the soil layer $\mathrm{i}[\mathrm{m} / \mathrm{s}]$

$\mathrm{k}_{\mathrm{s}, \mathrm{n}} \quad$ Hydraulic conductivity of the soil layer $\mathrm{n}[\mathrm{m} / \mathrm{s}]$

$\Delta \mathrm{X} \quad$ Layer thickness [m]

$\Delta \mathrm{t} \quad$ Time interval used for each iteration [s]

$\eta_{s, i} \quad$ Porosity of the soil layer i [\%]

$\eta_{s, n} \quad$ Porosity of the soil layer $n[\%]$

These equations refer to the process of filling the dry-well, when the moisture at the time $m+1$ is higher than the moisture at the time $\mathrm{m}$. The values of hydraulic conductivity were generically called $\mathrm{K}_{\mathrm{s}}$ in the proposed model.

Considering the moisture values of a given layer at the initial instant, the water level is obtained iteratively at that instant. From this, the minimum thickness of the 
soil layer, that is, the smallest relationship between hydraulic conductivity and drainable porosity is selected.

For the determination of the drainable porosity of the gravel layer, NM53 (ABNT, 2009) was used. Drainable porosity is the volume of soil pores in which water moves freely (Queiroz, 1997) and is similar to internal energy when considering the heat flux in solid media in the base domain.

Determining the drainable porosity in the field is complex, time consuming and expensive. Thus, it was considered an empirical equation for its determination.

Considering the compilation of equations presented by Ribeiro et al. (2007) and using the hydraulic conductivity of the soil of the experimental installation used for the validation of the proposed model, which will be described in the following $\left(\mathrm{k}=1.382 * 10^{-5} \mathrm{~m} / \mathrm{s}\right)$, the Chossat and Sagnac equation was selected (standard error of the estimate equals to 77.48 and correlation coefficient of 0.97 , when compared with experimental data), expressed in Eq. 13:

$$
\eta=0,025+0,0006 k^{0,5}
$$

where $\mathrm{k}$ - hydraulic conductivity [m/dia]

The depth of the soil, represented by the number of layers, can then be determined. Again, considering the base domain, the thermal thickness is similar to the equivalent soil thickness.

The thermal thickness is equivalent to the thickness of a material that conducts the same amount of heat over the same period of time as another element with different thickness and can be calculated by Eq. 14:

$$
\mathrm{Q}=\frac{\mathrm{Ak}_{\mathrm{x}} \Delta \mathrm{T}}{\mathrm{e}_{\mathrm{x}}}=\frac{\mathrm{Ak}_{\mathrm{y}} \Delta \mathrm{T}}{\mathrm{e}_{\mathrm{y}}}
$$

where:

Q Design flow rate $\left[\mathrm{m}^{3 /} \mathrm{h}\right]$

A area $\left[\mathrm{m}^{2}\right]$

$\mathrm{k}_{\mathrm{x}}$ Thermal conductivity of the material $\mathrm{x}$ $\left[\mathrm{kcal} / \mathrm{s} . \mathrm{m} .{ }^{\circ} \mathrm{C}\right]$

$\mathrm{k}_{\mathrm{y}}$ Thermal conductivity of the material $\mathrm{y}$ $\left[\mathrm{kcal} / \mathrm{s} . \mathrm{m} .{ }^{\circ} \mathrm{C}\right]$

$\Delta \mathrm{T}$ Temperature difference at the layer under analysis $\left[{ }^{\circ} \mathrm{C}\right]$

$\mathrm{e}_{\mathrm{x}}$ Thickness of the layer $\mathrm{x}[\mathrm{m}]$

$e_{y} \quad$ Thickness of the layer $y[m]$

Thus, to determine the depth of soil to be considered in the model, the water flow in the gravel layer was considered equal to the equivalent soil thickness, with the same surface area an at the same time. For this, Eq. 15 can be used:

$$
\mathrm{Q}=\frac{A_{\mathrm{b}} \eta_{\mathrm{b}} \Delta \mathrm{X}_{\mathrm{b}}}{\Delta \mathrm{t}}=\frac{A_{\mathrm{b}} \eta_{\mathrm{s}} \mathrm{e}_{\mathrm{s}}}{\Delta \mathrm{t}}
$$

where:

$\mathrm{e}_{\mathrm{s}} \quad$ Equivalent soil thickness [m]

$\eta_{\mathrm{b}} \quad$ Porosity of the gravel layer [\%]

$\Delta \mathrm{X}_{\mathrm{b}} \quad$ Gravel layer thickness [m]

$\eta_{s} \quad$ Drainable porosity of the soil [dimensionless]

The minimum thickness resulting of each layer of soil below the gravel layer in the experimental drywell is $0.09 \mathrm{~m}$. Thus, the equivalent thickness $\left(\mathrm{e}_{\mathrm{s}}\right)$ is $6.60 \mathrm{~m}$, that is, 73 soil layers to be analyzed in the model. The iteration process was considered complete when the water level reached the effective depth of the experimental drywell, that was defined as a function of its filling time.

To define the interface coefficients, TDA was also used and the base domain is composed by the thermal resistances. According to Kreith and Bohn (2003), when two surfaces with different conductivity are in contact, a resistance develops at the interface between them. Similarly, in the water flow in the soil, the hydraulic resistance (interface coefficient) can be also expressed in terms of the relationship between hydraulic conductivity and the cross area to the water flow.

Four interface coefficients were defined, which were incorporated into Eq. 9 to Eq.12:

- $\mathrm{C}_{\mathrm{ar}, \mathrm{b}}$ - interaction between water and gravel;

- $\mathrm{k}_{1} \quad$ - hydraulic conductivity around the dry-well;

- $\mathrm{k}_{2} \quad$ - hydraulic conductivity along the soil depth;

- $\mathrm{C}_{\mathrm{b}, \mathrm{s}}$ - interaction between gravel and soil; and

$-k_{3}$ - interaction of the holes in the side walls and the soil around the dry-well.

The interface coefficients were obtained by minimizing errors between the experimentally measured values and the filling times of the drywell.

The formulation of the equations for determining the interface coefficients was made using Buckingham's Theorem PI, which can be expressed by Eq. 17 (Fox et al., 2014):

$$
\mathrm{G}\left(\pi_{1}, \pi_{2}, \pi_{3}, \ldots \pi_{n}\right)=0
$$

where $\pi_{1}, \pi_{2}, \pi_{3}, \ldots \pi_{n}$ are independent parameters, which are obtained through the combination of predefined variables. From different types of equations, the one with the highest correlation coefficient with the measured data was selected.

The analogies were considered for the definition of the independent parameters are: design flow rate and heat flux; and cross-sectional area for water flow and cross-sectional area for heat flux. Thus, the equation for the gravel layer filling time was determined, based on the experimental design flow rates used for the determination of the interface coefficients, with the potential adjustment.

The resulting expressions are shown in Eq. 18 to Eq. 21. 


$$
\begin{aligned}
& \mathrm{h}_{\mathrm{b}}^{\mathrm{m}+1}=\mathrm{C}_{\mathrm{ar}, \mathrm{b}}\left\{\mathrm{h}_{\mathrm{b}}^{\mathrm{m}}+\left[\frac{2 \mathrm{k}_{1} \mathrm{k}_{2} \mathrm{k}_{\mathrm{s}, 1}\left(\mathrm{~h}_{1}^{\mathrm{m}}-\mathrm{h}_{\mathrm{b}}^{\mathrm{m}}\right)+\mathrm{Q}_{\mathrm{p}}}{\Delta \mathrm{X}}\right] \frac{\Delta \mathrm{t}}{\left(\eta_{\mathrm{b}} \Delta \mathrm{X}_{\mathrm{b}}\right)}\right\} \\
& \mathrm{h}_{1}^{\mathrm{m}+1}=\mathrm{C}_{\mathrm{b}, \mathrm{s}}\left\{\mathrm{h}_{1}^{\mathrm{m}}+\left[\frac{2 \mathrm{~h}_{\mathrm{b}}^{\mathrm{m}}-3 \mathrm{~h}_{1}^{\mathrm{m}}+\mathrm{h}_{2}^{\mathrm{m}}}{\Delta \mathrm{X}}\right] \frac{\mathrm{k}_{1} \mathrm{k}_{2} \mathrm{k}_{\mathrm{s}, 1} \Delta \mathrm{t}}{\left(\eta_{\mathrm{s}, 1} \Delta \mathrm{X}\right)}\right\} \\
& \mathrm{h}_{\mathrm{i}}^{\mathrm{m}+1}=\mathrm{C}_{\mathrm{i}, \mathrm{i}+1}\left\{\mathrm{~h}_{\mathrm{i}}^{\mathrm{m}}+\left[\frac{\mathrm{h}_{\mathrm{i}+1}^{\mathrm{m}}-2 \mathrm{~h}_{\mathrm{i}}^{\mathrm{m}}+\mathrm{h}_{\mathrm{i}-1}^{\mathrm{m}}}{\Delta \mathrm{X}}\right] \frac{\left.\mathrm{k}_{1} \mathrm{k}_{2} \mathrm{k}_{\mathrm{s}, \mathrm{i}} \Delta \mathrm{t}\right)}{\left(\eta_{\mathrm{s}, \mathrm{i}} \Delta \mathrm{X}\right)}\right\} \\
& \mathrm{h}_{\mathrm{n}}^{\mathrm{m}+1}=\mathrm{h}_{\mathrm{n}-1}^{\mathrm{m}}+\left(\frac{\mathrm{h}_{\mathrm{n}-1}^{\mathrm{m}}-\mathrm{h}_{\mathrm{n}}^{\mathrm{m}}}{\Delta \mathrm{X}}\right) \frac{\mathrm{k}_{1} \mathrm{k}_{2} \mathrm{k}_{\mathrm{s}, \mathrm{n}} \Delta \mathrm{t}}{\left(\mathrm{\eta}_{\mathrm{s}, \mathrm{n}} \Delta \mathrm{X}\right)}
\end{aligned}
$$

Results obtained with the proposed model were not significantly different from the data measured experimentally for the significance level of $5 \%$. The sum of residues (Fig. 5) resulted in 0.04 and the sample was equal to 1.12 , which meets the criteria established in Bussab and Morettin (2002). With the filling time, the effective depth of the drywell can be estimate using the Least Squares Method, based on (Eq. 22):

$$
\mathrm{H}_{\mathrm{D}}=\frac{\mathrm{Q}_{\mathrm{p}}\left(\mathrm{T}_{\mathrm{O}, \mathrm{G}-\mathrm{O}}+\mathrm{T}_{\mathrm{O}, \mathrm{G}}\right)}{\mathrm{S}_{\mathrm{p}}}
$$

where:

$\mathrm{H}_{\mathrm{D}} \quad$ = effective depth of the drywell [m];

$\mathrm{Q}_{\mathrm{p}} \quad=$ design flow rate $\left[\mathrm{m}^{3 /} \mathrm{h}\right]$;

$\mathrm{T}_{\mathrm{O}, \mathrm{G}-\mathrm{O}}=$ filling time of the drywell $[\mathrm{s}]$;

$\mathrm{S}_{\mathrm{p}} \quad=$ permeable surface composed of the gravel layer at the bottom of the drywell and the side holes $\left[\mathrm{m}^{2}\right]$.

$\mathrm{T}_{\mathrm{O}, \mathrm{G}}=$ filling time of the gravel layer $[\mathrm{s}]$;

Thus, the equation for determining the effective depth of the drywell resulted in Eq. 23, with $\mathrm{R}^{2}=0,999$ :

$$
\mathrm{H}_{\mathrm{D}}=1,094 \mathrm{Q}_{\mathrm{p}}^{-0,136}
$$

Considering the design flow rate of $6.54 \mathrm{~m}^{3} \cdot \mathrm{h}^{-1}$, which was used for the design of the experimental drywells, the effective depth is $0.85 \mathrm{~m}$. This value is approximately equal to the experimental depth $(0,87)$, which indicates the adherence of the proposed model.

\section{CONCLUSIONS}

The use of domain transfer via analogy enabled the development of a one-dimensional space-time model along the axis of the drywell that incorporates interface coefficients to simulate the three-dimensional water flow that occurs in water infiltration in the soil.

The modeled water level did not differ significantly $(p>0.5)$ from the data observed experimentally, which indicates the adequacy of the proposed model. The filling time determination according to the physical and hydrological characteristics of the place where the drywell will be installed consists of an advance in relation to the methodologies usually used for this purpose. The proposed model can be used in soils with similar hydraulic conductivities, surface drained by the drywell and gravel porosity, which demonstrates its versatility for different design situations.

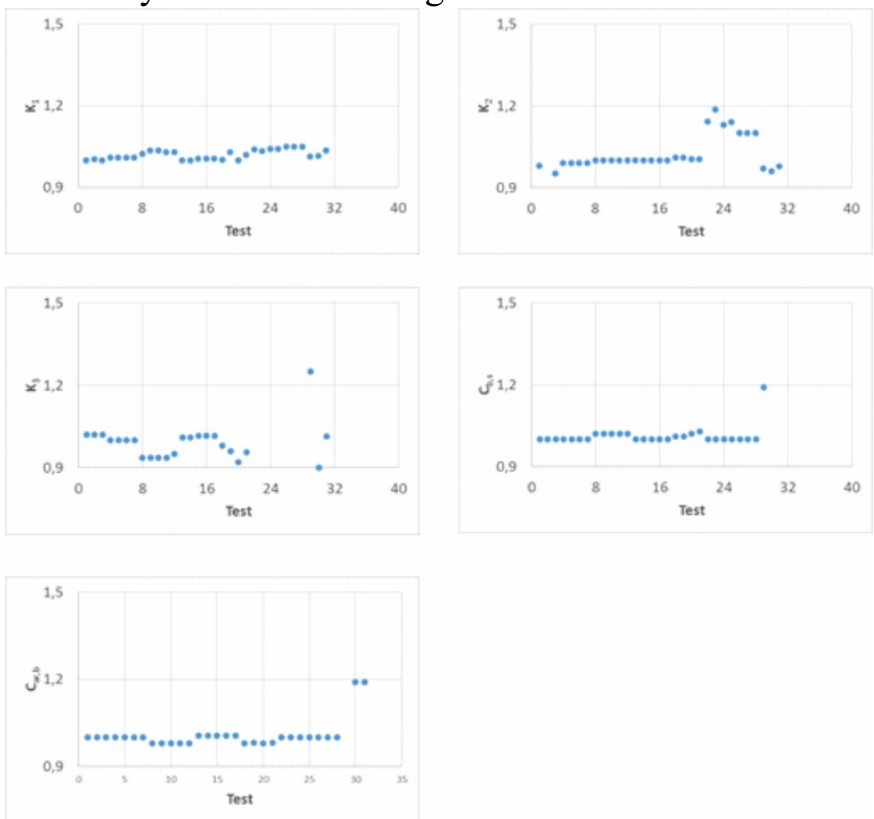

Fig. 5 Interface coefficients as a function of experimental design flow rates.

Acknowledgment CNPq (National Council for Scientific and Technological Development/Project 311525/2015-6)

\section{REFERENCES}

Arampatizis, G.; Tzimopoulos, C.; Sakellariou-Makrantonaki, M.; Yannopoulos, S. Estimation of unsaturated flow in layered soils with the finite control volume method. Irrig. Drain. v. 50, n. 4, p. 349-358, 2001 .

Aseka, I. B. Solução da equação de condução de calor bidimensional, em meios multicompostos, pelo método nodal, com parâmetros concentrados, e a técnica de transformada de Laplace (Solution of the two-dimensional heat conduction equation, in multi-composite media, by nodal methods, with concentrated parameters, and the Laplace transform technique). Tese de Doutorado (PhD Thesis) - Universidade Federal do Rio Grande do Sul. Porto Alegre. Rio Grande do Sul. 2003.

Aravena, J. E.; Dussailant, A. Storm-water infiltration and focused recharge modeling with finite-volume two-dimensional Richards equation: Application to an experimental rain Garden. J Hydraul Eng-Asce. v. 135, n. 12, p. 1073-1080, 2009.

Associação Brasileira de Normas Técnicas - ABNT. (2009). Agregado graúdo - Determinação de massa específica, massa específica aparente e absorção de água. (Coarse aggregate Determination of the bulk specific gravity, apparent specific gravity and water absorption). NM53, Rio de Janeiro, 8p. 2009.

Baca, R. G.; Chung, J. N.; Mulla, D. J. Mixed transform finite element method for solving the non-linear equation for flow in variably saturated porous media. Int. J. Nume.r Meth. Fl. International Journal for Numerical Methods in Fluids. v. 24, n. 5, p. 441-455, 1997.

Baker, L.; Ellison, D. Optimisation of pedotransfer functions using an artificial neural network ensemble method. Geoderma. v. 144, p. 212-224, 2008.

Bause, M.; Knabner, P. Computation of variably saturated subsurface flow by adaptive mixed hybrid finite element methods. Adv. Water Resour. 27(6), 565-581, 2004. 
Becker, M. A. Assessment of Downspout Disconnection by Modeling Infiltration Potential in Urban Areas. Master Thesis. Norwegian University of Science and Technology (NTNU). 160 p. 2016.

Bergamashi, L.; Putti, M. Mixed finite elements and Newton-type linearizations for the solution of Richards' equation. Int. J. Numer. Meth. Eng.. v. 45, n. 8, p. 1025-1046, 1999.

Burszta-Adamiak, E.; Mrowiec, M. Modelling of green roofs' hydrologic performance using EPA's SWMM. Water Sci. Technol., v. 68, n. 1, p. 36-42, 2013.

Bussab, W.O., Morettin, P.A. Estatística básica (Basic Statistics). Editora Saraiva. 526p. 2002.

Calvo, P.; Lisbona, F. A finite volume-multigrid method for flow simulation on stratified porous media on curvilinear co-ordinate systems. Int. J. Nume.r Meth. Fl. v. 37, n. 4, p. 375-397, 2001.

Christianson, R. D.; Brown, G. O.; Chavez, R. A.; Storm, D. E. Modeling field-scale bioretention cells with heterogeneous infiltration media. T. ASABE, v. 55, n. 4, p. 1193-1201, 2012.

Chua, L. H. C.; Wong, T. S. W. Improving event-based rainfallrunoff modeling using a combined artificial neural networkkinematic wave approach. J. Hydrol., v. 390, p. 92-107, 2010.

Cueto-Felgueroso, L.; Juanes, R. A phase field model of unsaturated flow. Water Resour. Res.. v. 45, n. 10, p. 1-23, 2009a.

Cueto-Felgueroso, L.; Juanes, R. Adaptive rational spectral methods for the linear stability analysis of nonlinear fourth-order problems. J. Comput. Phys.. v. 228, n. 17, p. 6536-6552, 2009 b.

Dashtaki, S. G.; Homaee, M.; Khodaverdiloo, H. Derivation and validation of pedotransfer functions for estimating soil water retention curve using a variety of soil data. Soil Use Manage.. v. 26, n. 1, p. 68-74, 2010.

Del Río, J. A.; López De Haro, M. A generalization of the Richards equation within extended irreversible thermodynamics. Water Resour. Res.. v. 27, n. 8, p. 2141-2142, 1991.

Dhikary, P. P.; Chakraborty, T.; Kalra, N.; Sachdev, C. B.; Patra, A. K.; Kumar, S.; Chandna, P.; Raghav, D.; Agrawal, K.; Sehgal, M. Pedotranfers functions for predicting of Indian soils. Aus.t J. Soil Res.. v. 46, p. 476-484, 2008.

Dorofki, M.; Elshafie, A. H.; Jaafar, O.; Karim, O. A.; Abdullah, S. M. S. A GIS-ANN-Based Approach for Enhancing the Effect of Slope in the Modified Green-Ampt Model. Water Resou.r Manag.. v. 28, p. 391-406, 2014.

Duchene, M.; Mcbean, E. A.; Thonson, N. R. Modeling of infiltration from trenches for storm-water control. $J$ Water Res PlASCE. v. 120, n. 3, p. 276-293, 1994.

Eliassi, M.; Glass, R. J. On the porous continuum-scale modeling of gravity-driven fingers in unsaturated materials: Numerical solution of a hypodiffusive governing equation that incorporates a hold-back-pile-up effect. Water Resour. Res.. v. 39, n. 6, p. 1-12, 2003.

El-Kadi, A. I.; Ge, L. The Courant and Peclet number criteria for the numerical solution of the Richards equation. Water Resour. Res.. v. 29 , n. 10 , p. $3485-3494,1993$.

Farthin, M. W.; Kees, C. E.; Miller, C. T. Mixed finite element methods and higher order temporal approximations for variably saturated groundwater flow. Adv. Water Resour. v. 26, n. 4, p. 373-394, 2003.

Furst, T.; Vodak, R.; Sir, M.; Bil, M. On the incompatibility of richards' equation and finger-like infiltration in unsaturated homogeneous porous media. Water Resources Research. v. 45, n. 3 , p. 1-12, 2009.

Furumai, H. Jinadasa, H. K. P. K.; Murakami, M.; Nakajima, F.; Aryal, R. K. Description of storage and infiltration functions of infiltration facilities for urban runoff analysis by a distributed model. Water Sci. Technol., v. 52, n. 5, p. 53-60, 2005.

Ferreira, A. T.; Reis, R. P. A.; Ilha, M. S. O. Using analogy of heat transfer by conduction and water flow in the soil for determining the overflow time of drywells. In: $42^{\text {nd }}$ International CIB W062 Symposium on water supply and drainage for buildings. Proceedings. Kosice, Slovakia. p. 386-394. 2016.
Fox, R. W.; Pritchard, P. J.; Mcdonald, A. T. Introdução à mecânica dos fluidos (Introduction to fluid mechanics). 8. ed. Rio de Janeiro: LTC - Livros Técnicos e Científicos S. A., 2014. 504 p.

Fytius, S. G.; Smith, D. W. Solution on unsatured soil moisture equation using repeated transforms. Int. J. Numer. Anal. Met.. v. 25, p. 1501-1524, 2001.

Gentner, D. Structure-mapping: a theoretical framework for analogy. Cognitive Sci.. v. 7, p. 155-170, 1983.

Ginting, V. Time Integration techniques for Richards equation. Procedia Computer Science. v. 9, p. 670-678, 2012.

Glass, R. J.; Yarrington, L. Mechanistic modeling of fingering, nonmonotonicity, fragmentation, and pulsation within gravity/buoyant destabilized two-phase / unsaturated flow. Water Resour. Res.. v. 39, n. 3, p. 1-7, 2003.

Goldsheger, N.; Chudnovsky, A.; Ben-Dor, E. Using reflectance spectroscopy and artificial neural network to assess water infiltration rate into the soil profile. Applied and Environmental Soil Science. v. 10, p. 1-9, 2012.

Graham, P.; Maclean, L.; Medina, D.; Patwardhan, A.; Vasarhelyi, G.. The role of water balance modelling in the transition to low impact development. Water Qual. Res. J. Can., v. 39, n. 4, p. 331342, 2004.

Green, W. H.; Ampt, G. A. Studies on soil physics. The Journal of Agricultural Science. v. 4, p. 1-24, 1911.

Haghverdi, A.; Cornelis, W. M.; Ghahraman, B. A pseudocontinuous neural network approach for developing water retention pedotransfer functions with limited data. J. Hydrol.. v. 6, p. 46-54, 2012.

Hou, T. Y.; Wu, X. H. A multiscale finite element method for elliptic problems in composite materials and porous media. $J$. Comput. Phys.. v. 134, n. 1, p. 169-189, 1997.

Huber, R.; Helmig, R. Node-centered finite volume discretizations for the numerical simulation of multiphase flow in heterogeneous porous media. Computat. Geosci.. v. 4, n. 2, p. 141-164, 2000.

Jain, A.; Kumar, A. An evaluation of artificial neural network technique for the determination of infiltration model parameters. Appl. Soft. Comput.. v. 6, n. 3, p. 272-282, 2006.

Jenkins, E. W.; Kees, C. E.; Kelley, C. T.; Miller, C. T. Na aggregation-based domain decomposition preconditioner for groundwater flow. J. Sci. Comput.. v. 23, n. 2, p. 430-441, 2001.

Ju, S. H.; Kung, K. J. S. Mass types, element orders and solution schemes for the Richards equation. Computers and Geosciences. v. 23, n. 2, p. 175-187, 1997.

Klenk, M., Forbus, K. Domain transfer via crossdomain analogy. Cognitive Systems Research. v. 10, p. 240-250, 2009.

Kreith, F; Bohn, M. Princípios de Transferência de calor.(Principles of heat transfer)Thomson.2003. 683 p.

Krebs, G.; Kuoppamäki, K..; Kokkonen, T.; Koivusalo, H. K... Simulation of green roof test bed runoff. Hydrol. Process.. Wiley. v. 30, n. 2, p. 250-262, 2016.

Lee, H. S.; Matthews, C. J.; Braddock, R. D.; Sander, G. C.; Gandola, F.. A MATLAB method of lines template for transport equations. Environ. Modell. Softw. v. 19, n. 6, p. 603-614, 2004.

Lee, R. S.; Traver, R. G.; Welker, A. L.. Continuous modeling of bioinfiltration storm-water control measures using Green and Ampt. J. Irrig. Drain. E.-ASCE, v. 139, n. 12, p. 1004-1010, 2013.

Levy, Y.; Ellis, T. J.. A system approach to conduct an effective literature review in support of information systems research. Informing Science Journal. V.9, P.181-212, 2006.

Li, Y.; Babcock Jr. R. W. Green roof hydrologic performance and modeling: a review. Water Sci. Technol... v. 69, n. 4, p. 727-738. 2014.

Lunatti, I.; Jenny, P. Multiscale finite-volume method for compressible multiphase flow in porous media. J. Comput. Phys. . v. 216, n. 2, p. 616-636, 2006.

Manzini, G.; Ferraris, S. Mass-conservative finite volume methods on 2-D unstructured grids for the Richards' equation. Adv. Water Resour.. v. 27, n. 12, p. 1199-1215, 2004. 
Mendes, N. Modelos para previsão da transferência de calor e de umidade em elementos porosos de edificações.(Models for predicting heat and moisture transfer in porous building elements) Tese de Doutorado (PhD Thesis). Universidade Federal de Santa Catarina, Florianópolis, 1997.

Nestorl, S. Y. Modeling the infiltration process with a multi-layer perceptron artificial neural network. Hydrological Sciences. v. 51, n. 1, p. 3-20, 2006.

Nikzad, J.; Eslamian, S. S.; Soleymannejad, M.; Karimpour, A. Numerical solution for one-dimensional Richard's equation using differential quadrature method. Current Science. v. 111, n. 6, p. 1028-1036, 2016.

Norambuena-Contreras, J.; Arbat, G.; Garcia, P. J.; Castro-Fresno, D. Nonlinear numerical simulation of rainwater infiltration through road embankments by FEM. Appl. Math. Comput. v. 219 , n. 4, p. 1843-1852, 2012.

Parchami-Aragui, F.; Mirlafiti, S. M.; Ghordani, D. S.; Mahdian, M. H. Point estimation of soil water infiltration process using Artificial Neural Networks for some calcareous soils. J. Hydrol. v. 481, n. 25, p. 35-47, 2013.

Queiroz, J. E. Um novo método de cálculo da porosidade drenável.(A new method of calculating drainable porosity). Rev. Bras. Eng. Agr. Amb., Campina Grande, v.1, p.117-119, 1997.

Reis, R. P. A. Avaliação de desempenho e modelagem numérica de sistemas de infiltração de água de chuva integrados aos sistemas prediais. (Performance evaluation and numerical modeling of stormwater infiltration systems integrated to buildings systems) Tese de Doutorado. (PhD Thesis) Programa de Pós-graduação em Engenharia Civil da Faculdade de Engenharia Civil, Arquitetura e Urbanismo. Universidade Estadual de Campinas, São Paulo. 2018 .

Reis, R.P.A.; Ilha, M.S.O. Comparação de desempenho hidrológico de sistemas de infiltração de água de chuva: poço de infiltração e jardim de chuva. Ambiente Construído v. 14, n. 2, p.79-90, abr./jun. 2014

Ribeiro, K.D., Nascimento, J.M.S., Gomes, N.M., Lima, L.A.; Menezes, S.M. Relações matemáticas entre porosidade drenável e condutividade hidráulica do solo saturado. Rev. Bras. Eng. Agr. $A m b .$, v. 11, p. 600-606. 2007.
Richards, L. A. Capillary conduction of liquids through porous mediums. J. Appl. Phys.. v.1, p. 318-333, 1931.

Schaap, M. G.; Leji, F. J. Database-related accuracy and uncertainty of pedotransfer functions. Soil Sci.. v. 163, n. 10, p. 765-779, 1998.

Solin, P.; Kuraz, M. Solving the nonstationary Richards equation with adaptive hp-FEM. Adv. Water Resour.. v. 34, n. 9, p. 1062 1081,2011

Srivastava, R.; Yeh, T. C. J. Analytical solution for one-dimensional, transiente infiltration toward the water table in homogeneus and layered solis. Water Resour. Res.. v. 27, n. 5, p. 753-762, 1991.

Tomasella, J.; Pachepsky, Y.; Crestana, S.; Rawls, W. J. Comparison of two techniques to develop pedotransfer functions for water retention. Soil Sci. Soc. Am. J.. v. 67, n. 4, p. 1085-1092, 2003.

Twarakavi, N. K. C.; Simunek, J.; Seo, S. Evaluating interactions between groundwater and vadose zone using the HYDRUS-based flow package for MODFLOW. Vadose Zone J.. v. 7, n. 2, p. 757 768, 2008

Upadhyay, S. N.; Agarwal, B. K. D.; Singh, D. R. On the low Reynolds number mass transfer in packed beds. J. Chem. Eng. Jpn.. v.8, p. 413-414, 1975.

Wu, L. Z.; Zhang, L. M.; Huang, R. Q. Analytical solution to 1D coupled water infiltration and deformation in two-layer unsaturated soils. Int. J. Numer. Anal. Met.. v. 36, n. 6, p. 798816, 2012.

Zaradny, H. Remarks upon numerical solutions of infiltration into a soil profile. Hydrological Sciences. v. 54, n. 2, p. 349-362, 2008.

Zhang, S.; Guo, Y.. SWMM simulation of the storm water volume control performance of permeable pavement systems. J. Hydrol. Eng., v. 20, n. 8, 2014.

Zuffo, A. C.; Leme, P. E. GRADEX e Santa Barbara: método híbrido para cálculo de vazão de projeto para macrodrenagem urbana. (GRADEX and Santa Barbara: hybrid method for design flow rate determination for urban macrodrainage) In: Simpósio Brasileiro de Recursos Hídricos. Anais. (Proceedings) João Pessoa, 2005 